\title{
Global Chinese migration in geographical perspective: a Kolkata (Calcutta) case study
}

\author{
Kunaljeet Roy ${ }^{1}\left[\right.$. Sukla Basu' ${ }^{1}$
}

Received: 7 September 2020 / Accepted: 22 November 2021 / Published online: 1 December 2021

(c) The Author(s), under exclusive licence to Springer Nature Switzerland AG 2021

\begin{abstract}
The contribution of migration to global demographic dynamics has resulted in a growing public and academic interest. The landscapes of Chinese overseas ethnic economy and associated migrant Diaspora networks require special scholarly attention from cross-disciplinary perspectives. The present study seeks to understand the same from geographical viewpoints and thus selected international migration theories have been applied upon the trajectory of Chinese overseas migration. For the last two centuries, this particular stream portrayed dimensional and structural shifts from single male sojourning to transnational family entrepreneurship. The global Chinese overseas associations promote ethnic solidarity, kinship ties and the sentiment of 'Greater China' over the foreign soils. The strategic geographical location of Calcutta, the then colonial capital of India played a vital role in the evolution of the ethnic enclave economic landscape in the spatial context. Hence, the authors by applying both theoretical and empirical methods have represented the Chinese migration to Kolkata (Calcutta) through twin Chinatowns as a case study with its varied dimensions to harness the perspective from spatial magnitudes.
\end{abstract}

Keywords Chinese overseas · Ethnic economy $\cdot$ Sojourning $\cdot$ Transnational family entrepreneurship $\cdot$ Kolkata China Town

\section{Introduction}

The contribution of migration to global demographic dynamics has resulted in a growing public and academic interest. Migration has been recently conceptualized as a function of capabilities and aspirations to migrate (Jorgen 2002) to urban areas or foreign lands. A new life or the search for a 'promised land' setting people on the

Kunaljeet Roy

kunaljeetroy@gmail.com

Sukla Basu

suklabasu@wbsu.ac.in; dr.basusukla@gmail.com

1 West Bengal State University, Barasat, Kolkata 700 126, India 
move; migration is 'a form of geographical mobility or spatial mobility between one geographical unit and another, generally involving a change in residence from the place of origin or place of departure to the place of destination or place of arrival' (Multilingual Demographic Dictionary 1958). Access to resources (money, knowledge and networks, improved infrastructure) and awareness of economic opportunities and lifestyles elsewhere are the determining factors. The most common explanation for migration as per conventional neoclassical and 'push-pull' models is international economic inequalities or wage gaps. Such 'push' factors in origin societies had been challenged by Piore (through the dual labour market theory in 1979) in which it is argued that with increasing education, greater female labour market participation and population aging, the number of natives willing and able to do manual agricultural, industrial and low-level service jobs has decreased. Rather it is stated that the structure and segmentation of labour markets in modern industrial societies creates a chronic and unavoidable demand for foreign workers. Similar was opined by Sassen (1991). Through empirical evidences and statistical analysis that economic inequality is not a necessary or a sufficient condition for substantial international migration to occur has been justified (de Haas et al. 2019). People need resources to move and are generally unlikely to migrate without concrete opportunities and prospects - such as jobs and family or network assistance in destination countries they argued. Thus poverty which was the earlier determinant or driving force no longer stands crucial. Moreover, a shift in preferences in terms of work, lifestyles and perceived material needs has resulted with the exposure to new images and ideas of the 'good life' (de Haas et al. 2019) via awareness through media and networking through online social platform.

According to Wang (1991) the Chinese emigrants started as 'merchants without empires' which also included all the skilled artisans who built the colonialists' cities in Southeast Asia. Through 'borrowed empires' of the European colonialists they carried on business and by close collaboration with them they opened China to the World and the World to China which has been termed as 'China's expansion overseas' (Zhongguo haiwei fazhan). Kuhn (2006) mentioned of the Chinese emigrants still participating in a five century process of building 'frontier enclaves'. Such enclaves are places where special rules allow Chinese and foreign business to develop. Consequently the 'Identity' issue became the burning focus particularly in the 1990s. As for the culturalist and structuralist approach the former explained the power and identity issues and the latter the economic activities of the Chinese diaspora. Structural transformation of once sojourner Chinese enclave economy to transnational financial corporation has evoked new dimensions of migration research. The bounded solidarity through kinship and cultural affinity, the Chinese overseas associations is depicting strong network ties with their latent 'Diaspora identity' (Baser 2014; Redclift 2017). McKeown (1999) highlighted the importance of networks while conceptualizing Chinese diaspora between 1842 and 1949 on a global framework. Mid 1990s paved the way towards transnationalism being influenced by globalization and with it, diaspora studies following suit. The changing framework in research on the Chinese overseas through a 'diasporic perspective' calls for a detailed investigation on the case study of Kolkata. In the understanding of Chinese migration and the identity issue of Chinese living among non-Chinese in Kolkata 
the paper is based on the findings notably of Wang (1991) who conceptualized into four categories: (i) the huashang as the merchants or artisans sent abroad (in Australia) who created huiguan (district) social institutions to maintain their Chineseness identity or for mutual aid. The (ii) huagong or coolie pattern of migration, the (iii) huaqiao as a migratory pattern referring to those Chinese born in China but residing temporarily abroad as sojourners. The term became an important political term of reference for Chinese governments wishing to call upon the loyalty of these sojourners. Huaqiao retain and maintain cultural and even political allegiance to China through infrastructure of organizations, newspapers and schools which too were set up in this city of Kolkata. (iv) Huayi is a migratory pattern as well as reflecting their identity. Ling-chi Wang's (1991) typology (cited by Chan 1999) on identity issue in accordance with the Chinese Americans is also applicable in the case study of Kolkata based on the 'Anti-Chinese' to 'Pro-Chinese' administrative ventures. The term 'Chinese Overseas' after Gungwu has been adopted in the paper instead of 'Overseas Chinese' in the description of all ethnic Chinese migration since the term 'Overseas Chinese' is a specific pattern of Chinese migration, its literal translation into English is after Gungwu's huaqiao.

Against this backdrop "Objectives and methods applied" section highlights the key questions and puts forth the objectives and methods applied. The trajectories of Chinese Overseas migration from a historical-geographical perspective is in "Trajectories of Chinese overseas migration: a global (historical-geographical) perspective" section. Theorizing and conceptualizing Ethnic Chinese Overseas migration is in "Overview of studies on ethnic Chinese migration" section. Those facts/information that do not add anything new to our understanding of the Chinese Overseas immigration (in the context of Kolkata) are not cited in details in "Trajectories of Chinese overseas migration: a global (historical-geographical) perspective" and "Overview of studies on ethnic Chinese migration" sections. Section Chinese overseas in India has emphasized on the case study of Kolkata Chinatown from theorizing the history of the Chinese in Kolkata to recent overseas diaspora. The concluding Section summed up the main arguments of the paper.

\section{Objectives and methods applied}

This paper attempts to conceptualize and explain (i) the relationship between the significance and meaning of micro-social actions of the Chinese overseas immigrants residing in the twin Chinatown of Kolkata and larger-order structures at the international scale; and (ii) to understand the socio-spatial dynamics driving socio economic phenomena associated with the Chinatown landscape. The aim of this article is to evaluate the migration dynamics of residents from mainland China crossing the international border from pre-colonial through the post-liberalization era till present times particularly in Kolkata.

Finding out the name places from old maps and other literary sources we tracked the streets, the neighbourhood, the socio-cultural and socio economic imprints of colonial Chinese landscape of the twin Chinatown in addition to the earliest immigration point of arrival from China at Achipur. We then identified the major areas of 
residence and the commercial enterprises and did our survey using a semi-structured questionnaire and a GPS. Snowball sampling, online social media communication network made our venture a robust participatory one. We also participated in their recent events, bought their ethnic food products and had a taste of their food in various restaurants (traditional and new) to gain familiarity as an outsider researcher with a serious researching interest. Gaining familiarity we earned the trust of both the aged and the youth through our interactions (be it face to face or through social media). We visited their institutions and had access to their magazines and newspapers, Diaries and Yellow Pages. We kept the ethical issues in mind asking for prior permission while using audio-visual aids; the interviews were pre-fixed and later transcribed. Regarding sentimental issues on impact of 1962 conflict or on identity issue we were careful not to disclose their identity on the field and even in this paper. Our literature search engine was based on the online version available from several journals notable among them is the interdisciplinary journal-the Journal of Chinese Overseas which covers certain broad issues. The Documental Websites of Overseas Chinese Studies' page lists the international research associations, research and documentation centres in various parts of the world. Those which were of the open accessed category could be referred. Books were consulted notably of Shelly Chan's 'Diasporas Homeland: Modern China in the Age of Global Migration' (2018). Wang (2000)'s themes of identity, policies of the homeland and the host societies, the basic migration patterns of labourers and traders, with a long term overview of the Chinese overseas experience was beneficial. Kuhn (2006, 2008)'s macro historical overview of Chinese emigration since the seventeenth century has been particularly useful as it covers different migration phases, adaptation patterns and networks. The understanding of the evolution of the field of Chinese overseas studies is from Liu (2005). A bibliographic detailed reference was drawn from Liu and Dongen (2016)'s 'The Chinese Diaspora Chinese Studies Oxford Bibliographies'. The book is significant to us as it includes thematic wise definition and origins among others. Ma and Cartier eds. (2003) is of special interest as it has dealt with the geographical concepts of space, place, transnational mobility and place related identity through which our perception on Chinese overseas residing in Kolkata could be expressed. Various Governmental Reports and documents available offline and online were useful. Files of Indian intelligence and police reports containing information about business, associations, schools and other institutions are available to the public until 1947 which too have been availed through literature search. The research works of Poston and Wong (2016), de Haas et al. (2019) and the report by Goodkind (2019) updated the recent documentation in this study.

\section{Trajectories of Chinese overseas migration: a global (historical-geographical) perspective}

The source regions which generated the Chinese overseas migration are depicted in Fig. 1. Scholars noted 1860s to be the beginning of emigration of the Chinese from China. The phenomenon of emigration of Chinese was on account of several internal and external events. Notable were the change over from the Ming to the 


\section{Chinese Overseas source regions}

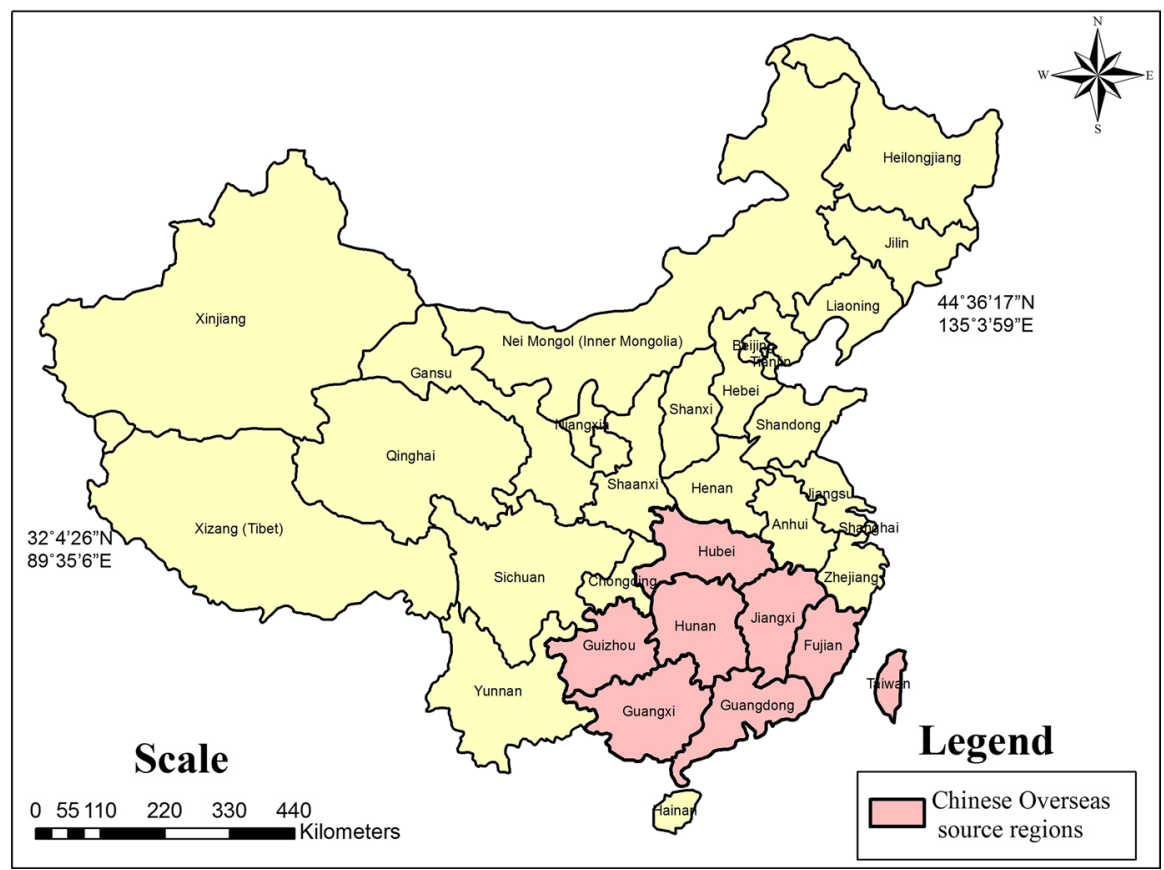

Fig. 1 Chinese Overseas source regions

Manchu dynasty in the middle of the seventeenth century with the consequent civil strife. With the penetration of European entrepreneurs and the pouring of Western capital into Southeast Asia there was a call for labour paving the way for thousands of adventurous emigrants from South China into colonial South-East Asia. Exodus in emigration from mainland China resulted with contacts with the Europeans notably the Portuguese who established Macao as a trading port in 1557 (Mizuoka 1976/2017; Yee and Lo 1991). The colonial ports serving as specially-protected frontier enclaves (Kuhn 2006) offering Chinese merchants a reasonably hospitable venue of doing business was an added advantage. Chinese and European commerce proceeded unhampered by the structures of the homeland regime. In the mid-nineteenth century, a second type frontier enclave, the treaty ports on the China coast emerged in addition to these colonial venues.

Tracing the history of Chinese overseas migration from mainland China to varied destinations, either through desperation or driven by political turmoil, the 'treaty ports' (Downs 1997; Nield 2015; Bracken 2018) situated in the coastal provinces of China acted as driving engine to search for new destinations. Bracken (2018) in the article on the genesis and influence of treaty ports in China put forth the first (1839-1842) and second (1856-1860) Opium wars (Downs 1997; Nield 2015; cited by Bracken 2018; also mentioned by Mei 1979) as the major discourse of political happenings behind the emergence of treaty ports. After the Opium War under the 'treaty system', Western power was clamped upon Chinese seaports (Kuhn 2006). 
This was the period of the infamous 'coolie trade'. Kuhn (2006) stated that, by the end of the period of 'Asian Revolution', the Chinese overseas migration towards Southeast Asia halted as the emergence of a Communist regime in mainland China (PRC) fuelled dissension among those overseas due to the political and ideological divergence between the Kuomintang and the Communists. This internal dimension and dynamics of political ideology too affected Chinese overseas migration. Zerba (2008) discussed PRC's Overseas Chinese strategy having two different dimensions: one domestic and the other foreign. The foreign or international dimension involved the ethnic Chinese abroad and those countries where their niche was established. The domestic dimension emphasized on two separate groups of Chinese overseas: the domestic Overseas/relatives of the overseas and the returned overseas. Similar to that of the Kuomintang or Nationalists, the Communist authority established the Overseas Chinese Affairs Commission (OCAC) to control both the dimensions. The Commission coordinated with other Governmental agencies settling issues related to protecting Chinese overseas interests as well as keeping attracting funds from the overseas/returnees. The Chinese overseas were dealing with the dual nationality issue then.

Post second World War policies related to migration became more liberal with migration shifts predominantly becoming directional. Migration streams shifted dramatically from Southeast Asia towards North America and Australia. New streams of immigrants were also attracted to Europe including emigrants from former colonial territories. Chinese Premier Zhou Enlai recognized the existence of an 'Overseas Chinese' problem in the first National People's Congress, 1954 (Zerba 2008) where he urged these Overseas to obey the local laws and customs of those host countries. The statement indicated towards the possible future policy of the PRC towards the overseas. Gradually, huaqio became huaren (ethnic Chinese or Chinese overseas), who adopted local citizenship and placed their political allegiances with the residing nations. Huaren in English meaning 'ethnic Chinese' refers to those Chinese living outside China who are not the citizens of mainland China. The term was created by Malaysians and Singaporeans with the aim to differentiate themselves from the mainland Chinese (Suryadinata 2015). Hence the connotation 'huaren' has different geographical context compared to 'huaquio' (which was the earlier term used for indicating overseas Chinese).

The most recent period (1980-present) witnessed new migrants originating from the PRC beginning to occupy a greater proportion among the overall Chinese emigration. Cheap transport and electronic communication, the post-Mao reopening of China, permitting freer interaction with the homeland gave a new dimension to the migration pattern. Major shifts in Chinese emigration patterns took place in the age of global integration (Kuhn 2006): the emergence of new ethnic identities and different places of origins of emigration (Liu 2005). The contemporary new migrants can be categorized into four major types: students turned migrants (those studying abroad, but staying semi-permanently outside China after graduation), emigrating professionals (emigrating to the west for professional reasons), chain migrants (joining family and acquaintances who became foreign citizens) and illegal immigrants (going overseas by the way of human trafficking, forced migration or through temporary visas) (Liu 2005). Remittances by overseas residents to their country of 
origin provide a sense of the economic ties associated with international migration and also reflect the local economic conditions. More than US\$60 billion was remitted to China through official channels according to the World Bank as of 2017 (Goodkind 2019).

\section{Overview of studies on ethnic Chinese migration}

Modern migration policies are instruments of migrant selection, based on skill, wealth or family background of migrants. There has been a declaration of liberalization since the 1990s (de Haas et al. 2018) relating to migration policies. Liberal immigration systems are mentioned to be a feature of liberal economic systems rather than a characteristic of demographic governance per se. The dynamics of Chinese Diaspora has been given a new outlook by Shelly Chan's 'Diaspora moments' (2018). The first moment considers the legacy of International coolie trade in which Qing court permitted (in 1893) the return of overseas Chinese to their homeland. The Qing court's active intervention thus played a significant role in the global trade in Chinese coolie labourers. The second moment in 1920's portrays Chinese as colonialists, as intellectuals much different from the stereotyped forced and reluctant travellers. The third moment is on Confucianism and Chinese identity; the fourth is outcome of tension between official policies and local realities in the context of stay-behind wives of emigrants in South China in 1950s. Decolonization and antiChinese sentiments in South-East Asia led to the fifth moment of returnees ( $g u i$ qiao) in the 1950s and 1960s. Among the four typologies of Chinese migration abroad identified by Gungwu (1991), current student migration is identified closest to his 'Huaquio' - the extended sojourn of an already well-educated professional. That more than $90 \%$ of students are self-funded (Luo 2017) indicates that Chinese families are willing to invest in their children's overseas education with the growing prosperity of the middle-class Chinese. Hence the increase in the number of students departing from China to study abroad has risen sharply in recent years making China as the number one country of origin for international students in the United States. The older traditional categories of migration of Wang (1991) 'Huagong' (migration to work on labour projects) continues but the forms and destinations have changed. At the end of 2016, about half of these overseas labourers were concentrated in Macao, Japan, Singapore, Hong Kong and Saudi Arabia (extracted by Goodkind 2019). In the first four of these countries the labourers were mostly employed on projects constructed by Chinese companies.

As for 'Huashang' after Wang's (1991) classification based on migration to develop trade and commercial businesses- Africa is one of the newest destinations along with the most rapid diasporic growth. Those who have sought investor visas comprise another notable category. Many countries provide opportunities for individuals to obtain permanent residence if they make investments that stimulate the economy and/or create jobs in the host country. Such destinations aspired for are USA, Canada, Hong Kong, Australia, Singapore and the United Kingdom.

The Identity issue has been taken up based on racial perspectives ranging from the 'Anti-Chinese' to 'Pro-Chinese' administrative ventures from Canada. The Chinese 
Exclusion law (1923-1947) restricted Chinese overseas entry to Canada until mid twentieth century (Wong 2007) thus culminating in a sharp decline of the Chinese population during the 1930s and 1940s. Their political and civil rights were also lost due to a series of municipal, provincial and federal legislation passed in the late nineteenth century to early twentieth century ( $\mathrm{Li}$ and Lee 2005). Institutional regulations and/or discriminatory laws also prompted early Chinese to select non-elite occupations (Lo 2006). Chan (1999) by citing Wang Ling-chi's (1991) typology of zhancao chugen (eliminating weeds by pulling out the roots) marked about the racial discriminatory practice of 'Anti-Chinese' towards the American-born Chinese prior to the Second World War. It was similar to hyuai identity in response to the discriminatory practice of the White Australian period in which many of the Chinese sought acceptance of the host country with an assimilation mentality by several survival strategies. However, 'Pro-Chinese' steps or the accommodative strategy of the hyuai settling down in the foreign lands encouraged immigrants to transform to family-based operations when restriction was called off on single male sojourners after 1947. In 1967 the shift from a "race-based" immigration policy of the Canadian government opened the doors to an influx of immigrants irrespective of any race. The post-globalization era experienced a large scale influx of overseas skilled professionals and students aspiring higher education, especially after the Tiananmen Square incident of 1989 (Li 2005).

To address the lacuna of research in the context of some migration theories and contemporary trends with that of the Chinese Overseas of Kolkata, the specific objectives are based on the trajectory of Chinese Overseas migration at the global level in which impacts of anti-Chinese sentiments, prohibition 'laws' and pro-Chinese Acts have been addressed. We find that the aforesaid global trajectories of Chinese overseas migration referred by Wang (1991) and Chan (2018) are applicable in our case study of Kolkata where the Chinese Overseas have marked a significant impact on city's vibrant cultural landscape and also replicate their immigrant identity through their traditional entrepreneurial ethics. The scrutiny based on the case study of Kolkata Chinatown addresses the global-local linkage in context to migration theories for a comparable conceptual wise and trend pattern wise analysis. Very few Indian or Chinese researchers have undertaken in-depth studies of the Chinese communities in India wrote Tansen Sen in the Foreword to the book entitled 'Preserving Cultural Identity through Education: The Schools of the Chinese Community in Calcutta, India' by Zhang Xing (2010). This inspired us to take up the case study of Kolkata (Calcutta) Chinatown unique on its own: the physical proximity and feasibility being added advantage for us. These enabled further insight into the course of establishment of an ethnic identity in a foreign land through livelihood patterns and strategies adopted by the Chinese in Kolkata. Imprints of these has been traced by us in Kolkata Chinatown and discussed elaborately in the following section.

\section{Chinese overseas in India}

This section has focused on this little known Chinatown of South Asia on which researching has also been meagre. Where a large number of Chinese reside in a country other than in China there is integration between two distinct elements one in 
racial context - the 'Chineseness' and another in spatial context-the 'Chinatown' or Chinese ethnic enclave (Frazier et al. 2010). A Chinatown presents an image of a space in the city which could be defined as Chinese with living quarters or as an agglomeration of business enterprises, or as a concentration of both Chinese residence and business in one area. This 'Chinese space' portrays some visible symbolization of Chinese way of life connected with their motherland. It is the space where the Chinese population negotiates with the host society and the local administration in various spheres of daily encounters (Sales et al. 2009) as an accommodative/ assimilation strategy. Such Chinatowns of a highly territorial organization of an ethnic group is to be found across all continents. Various opinions on this space prevail: as a tourist attraction, an identity, a root of Chinese heritage in the host society, a low rent neighbourhood for poor and elderly people; even as a reception area for new immigrants who have problems assimilating into the host society (Lai 1988). Liu and Dongen (2016) in their bibliography on Chinese overseas had devoted a small coverage of Kolkata Chinatown under a subsection on smaller communities elsewhere 'to give the reader a more complete picture of the geographical dispersion of the Chinese overseas'. 'Smaller' indicates the size in population of the community compared to the global ones is meagre. In this Bibliography the anthropological account of the Hakka Chinese working in the tanning industry and some general issues of Chinese diaspora by Oxfeld (1993) is mentioned.

India, like any other colonial land, having commercially significant port cities like Calcutta (renamed as Kolkata) and Bombay (now as Mumbai) initially housed stream of Chinese overseas male sojourners reflecting Wang (1991)'s huagong or coolie pattern of migration and representing a bachelor society. These sojourners started establishing temporary Chinese ethnic coolie enclaves near the dock areas of Calcutta (Kidderpore dockyard around the Calcutta Port) and around the Mazagon dock area of Bombay (Fig. 2). Calcutta has been renamed to Kolkata in 2001 and so the city is mentioned in the paper as per the temporal discussion. The Chinese perceived British India as a lucrative place due to the economic prospects of the country. Attracted by the image of India as the 'land of opportunities' with the reputation of 'a rich country with good governance', the Chinese perceived India as a 'promised land' with access to resources and a beneficial place to work and earn a livelihood since work in China was scarce and wage rate was also very low. With the money earned in India, they returned to their homeland to take a break from their work and spend time with their families. They were warmly welcomed back and the bachelors were very prospective grooms for the girls in China. When one went back to China, someone else took his place in the city concerned: thus securing the job out here in India (then Calcutta) returning usually back to the work when the money ran out at home (Roy and Basu 2020).

The initial 'push' stimuli from the 'treaty ports' with the internal turmoil and pull factors such as good governance and commercial prosperity of Calcutta as the second city of the British empire, invited the Chinese sojourners to this colonial port based city. The strategic geographical location of Calcutta the colonial capital city, acted as the pivot area for 'overseas Chinese ethnic heartland' in India which later diffused to other places of West Bengal (Darjeeling, Malbazar, Asansol, Durgapur, Howrah, Chandernagore and Bansberia); to eastern India 


\section{Dock (Port) based Chinese enclaves in India}

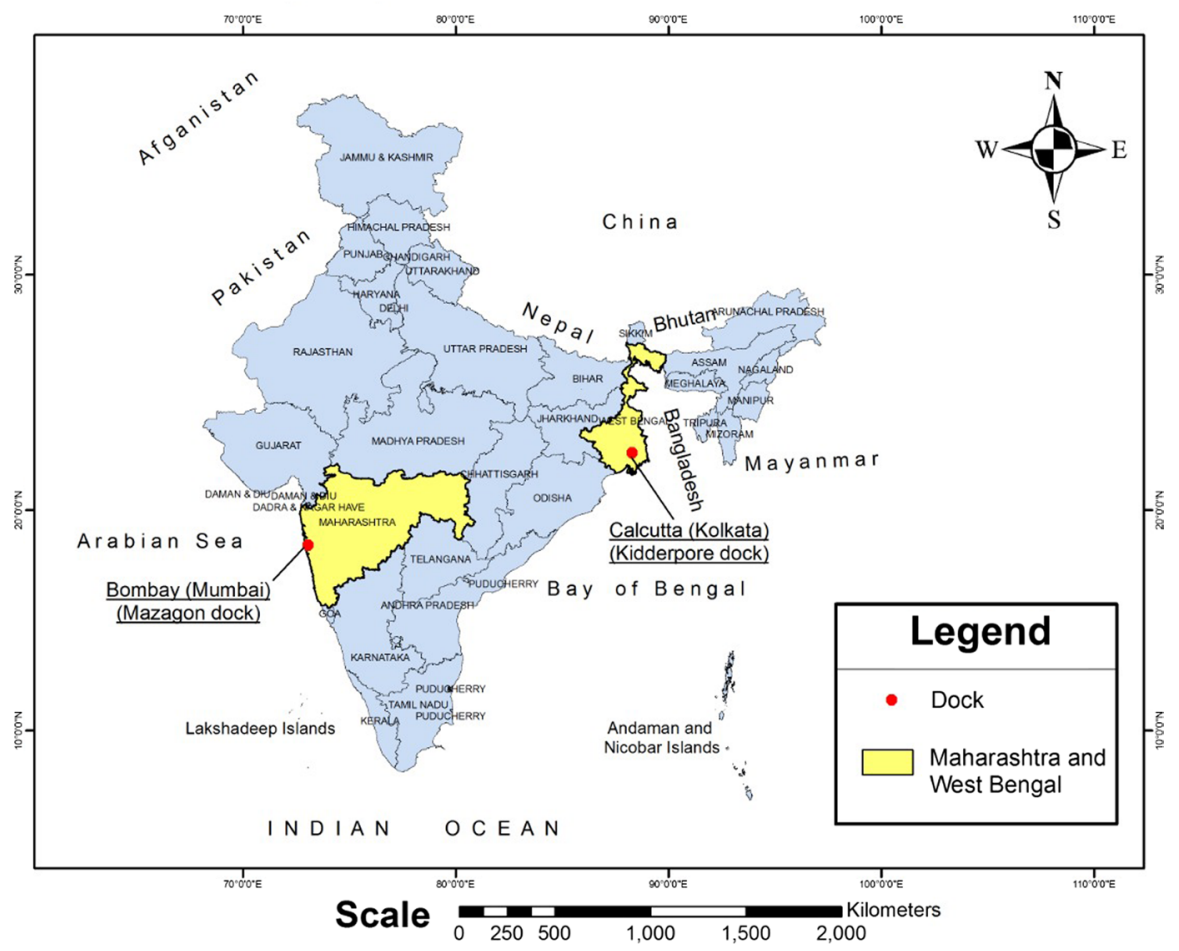

Fig. 2 Dock (Port) based Chinese enclaves in India

(Odisha) and north-eastern India (Assam, Meghalaya). China-focused education was offered to children of Chinese immigrant communities (huaqiao) residing in these areas when later the composition of Chinese residents were transformed by the immigrants from bachelor society. Chinese medium schools for the Chinese in India were established in cities of Bombay, Darjeeling, Kalimpong and Shillong (Zhang 2010a, b) besides Calcutta for preserving Chinese identity among immigrant communities. This was a direct attempt at indoctrinating children in their formative years with their culture and their roots, their basic values and manners (Liang 2007). Uncertain future of the return to China for the immigrant communities made it necessary to establish these educational institutions as the huaqiao retain and maintain cultural and even political allegiance to China through infrastructure of organizations, newspapers and schools. This is similar to third moment after Shelly Chan (2018).

The phenomenon of Chinese overseas migration to the colonial port cities in India too has a direct socio-political connection with the notion of the 'Treaty Ports' of eighteenth century. Political incidents like Opium wars (1839-1842 and 1856-1860), Taiping Rebellion (1850-1864), Japanese invasion (1931-1932) of Manchuria staged different phases of Chinese overseas migration in the country. 
The then colonial ports of Calcutta, Bombay, Madras (of India) and Colombo (of Sri Lanka) had frequent maritime exchanges with the Far East. These ports also served as specially-protected frontier enclaves (Kuhn 2006) offering Chinese merchants a reasonably hospitable venue of doing business. European shipping companies also used these ports to undertake repair and maintenance work on their ships. Cantonese carpenters worked at these ports and received high remunerations, reportedly at par with the American and European workers (Zhang and Sen 2013). Based on ancestral crafts these Cantonese were engaged in carpentry having adopted the skill from China thus not distancing and disassociating themselves from the Chinese community. They were recruited by companies and private individuals to work at shipyards and railway companies in South Asian cities. As an example in 1930s, there were 178 Cantonese carpenters functioning for the Greater Indian Peninsular Railway Company in Bombay (Tan 1933, cited by Zhang and Sen 2013). Some were engaged in making wooden tea containers in North Eastern India, particularly in Assam and Meghalaya.

\section{Chinese overseas in Calcutta: the roots of Calcutta Chinatown}

The literary sources of Alabaster (1858), Grant (1862), Oxfeld (1993) and Liang (2007) mentions the Chinese runaway sailors and labourers, working around Calcutta port as fitters, carpenters and establishing their 'coolie' enclave belonging mainly to the Cantonese community. Even now relics of Chinese enterprises are traced in some selected spaces of Kidderpore, Ekbalpur and Metiabruz, Garden Reach and Behala near the port. Near the naval shipbuilding areas of Garden Reach and Kidderpore dock we searched the available cartographical records of the city. We found in the Atlas of the city prepared by National Atlas and Thematic Mapping Organization (NATMO) in 2010, a now lost Chinese enclave, popularly known as 'Chinapara' ('para' is a local Bengali word meaning neighbourhood). We traced it (now 'Chinapara Basti'/slum) in between the Garden Reach Road and Khansama Para Lane beside the Imambara Mausoleum in ward number 135 under the Kolkata Municipal Corporation (KMC). The most agreed upon view on the earliest immigration from China to Calcutta however, dates back to 1778 with a native Chinese sailor cum trader Yang Dazhao arriving in Calcutta from Canton (Zhang and Sen 2013). Oxfeld (1993) mentioned that Tong Achi/Atchew arrived at Calcutta for establishing a sugar manufacturing unit and was granted land near Budge Budge port $33 \mathrm{~km}$ away from Calcutta by the then Governor General Warren Hastings. (Fig. 3). The place has earned the name of Achipur after him. This marks the beginning of Chinese economic entrepreneurship in the city of Calcutta. Atchew faced hurdles in functioning of this enterprise as bulk of his recruited Chinese workers was lured to work at the Calcutta port. This indicates the growing demand for Chinese labour in the dock area towards the end of the eighteenth century.

The Cantonese community was followed by the Hakkas in their entry to the city. Oxfeld (1993) by citing Cohen (1968) pointed towards the out migration of the Hakka community from the northern parts of China towards the southern coastal areas; later through the said ports they further extended their streams. She marked 


\section{Achipur-Calcutta Linkage}

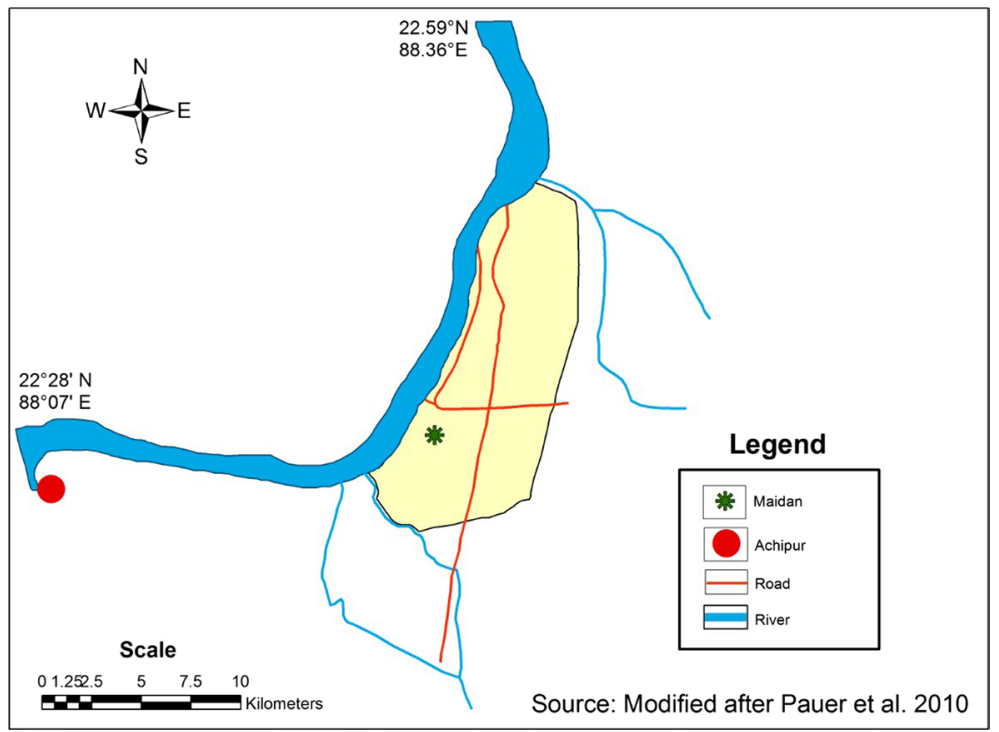

Fig. 3 Achipur-Calcutta Linkage

the notion of 'guest people' on the Hakkas. The initial drive of fortune seeking in distant soils was economic; however with changing socio-political circumstances and continuous turmoil bulk increase in emigration from China, especially from the coastal provinces like Guangdong, Guanxi and Fujian, Hunan, Hubei provinces took place. According to Pauer et al. (2010) the proportion of the Chinese Overseas communities approximately of the total in Calcutta are as follows: the Hakkas constituted 45\%, Cantonese 40\%, Hupeh/ Hubeinese $10 \%$ and Shanghaians about 5\%.

Oxfeld (1993, 2005, 2007) and Liang (2007) explained the early pattern of 'Chain Migration' and how the 'Chinese single male' migrant pattern (the concept of 'sojourning') transformed to a family-based entrepreneurship in Calcutta. A new wave (the second wave) of Chinese immigrants to the city towards the end of the nineteenth century due to political unrest in China led to a spatial expansion in the Bow Bazaar area of Central Calcutta with its associated residential, socio-cultural and economic institutions. This marks the beginning of Chinese overseas family entrepreneurship in which family members of women and children faced accommodation problems as the existing dormitories and dwelling places were only for single men residing here. Limited economic opportunities for women also were a hindrance (Liang 2007). However they sustained themselves by working for even eighteen hours a day on the non-ethnic work of washing clothes, selling liquor, tailoring, apprenticeship under carpenters and vending vegetables in markets. Worse conditions in China forced them to carve out a livelihood in the city. Political instability in mainland China hindered the wish to return to their motherland and they started building community assets which enabled the co-ethnic link between the residential enclave community and the ethnic entrepreneurship. Consequent migration 
from different provinces of Southern China to Calcutta created the dimensional variation of ethnic professions/economic activities among the Chinese immigrants leading to a sectoral specialization and to the formation of twin Chinatown.

\section{Chinese ethnic economic enclaves in Calcutta}

The occupational specialties were divided among regional origins with these overseas immigrant communities carrying their legacy of ancestral professions familybased co-ethnic entrepreneurial strategy. The earliest economic enterprise was associated with a series of Cantonese carpenters migrating to Calcutta port for working under British Government during the mid-19th Century residing in the Tiretta Bazaar area, the CBD of the city culminating in the old Chinatown of Calcutta- the Cheenapara. Business relation between the Southern provinces of China, particularly Guangzhou (Canton) and Calcutta began to expand due to opium trade. The Hakka tanners moved into this part of the city followed by the Hubeian dentists and the Shanghaian dry cleaners in the early twentieth century. The communities were marked by the host society inside Kolkata in respect of their economic niche, i.e. Cantonese carpenters, Hakka tanners and shoe makers, Hubeinese or Hupeh dentists, Shandong silk traders and Shanghai dry cleaners.

\section{The Cantonese carpenters and furniture makers}

Although many of the Cantonese worked in Calcutta port area but they were mostly carpenters. Those hailing from especially the Sze Yap, from the region of Guangzhou and Pearl river delta in southern China initially occupied the leading position in the Chinese community in Calcutta. They were the earliest immigrants to India and worked on the contract jobs for the British Govt. They advanced from being part-time workers and contract labourers to factory owners and started to establish various carpentry shops and enterprises in central Calcutta, the CBD, near Bow Bazaar area. In the 1950s, there were nearly or more than 300 Cantonese carpenters found working in the shipyards of Calcutta port/dock areas and also were carpentry units run by Cantonese (more than 20) in Calcutta as marked by Yu (1956) cited in Zhang and Sen (2013).

\section{Hakka shoemakers and tanners}

The Hakka community mainly migrated from Guangdong province in China with some who migrated through Thailand and other Southeast Asian regions. Unlike the Cantonese, the Hakka immigrants were mostly unskilled during their arrival in the Indian subcontinent; a majority acquired the skill of shoe making and leather tanning after their arrival in India (Liang 2007). The Hakka run shoe units were established at 'Koshaitola' (now Bentinck Street) at Tiretta Bazaar or older Chinatown which being cosmopolitan served an elite class and thus shoe shops were set up in this part of the city. The higher castes or classes tended to concentrate at the centre and so called untouchables or lower classes had to reside at the peripheral portions of Calcutta as cited by Bose (1968). According to the Hindu 
caste system, the work of a cobbler is considered as occupation of the untouchables. With few local Indians working in the skin tanning and shoemaking industry, some of the Hakkas found it easier to enter into this trade. They engaged the lower clan native workers from Bihar (adjacent province to Bengal) who migrated from their native spaces to Calcutta in search of a better livelihood. Those Hakkas dealing with leather materials (considered polluted as per Hindu beliefs) had no other option but to stay away from the majority of populous core of the city and migrate to marshy vacant parts of the city the then outskirts to Tangra that had ample supply of waste water for tanning operations serving as an ideal spot for tanning processes, thus forming the second Chinatown of Kolkata at Tangra (Dhapa) area. In the first half of twentieth century, the Chinese tanning units were thus established here. Chinese population of the city thus spread across the eastern flanks of Topsia, Tangra and part of Park Circus area (presently wards of 58 and 66 of Kolkata Municipal Corporation). These Hakka Chinese tanners created a huge ethnic business cum residential cluster along Tangra and Matheswartala road near Dhapa converting the area into a unique Hakka entrepreneurship with an ethno-commercial hub of community run tannery units, Chinese schools, clubs, cemetery making Tangra a symbol of city's 'Chineseness'.

A striking concept associated with Chinese overseas migration is the concept of 'middleman minorities' developed by Bonacich (1973) who are groups that fill a status gap between the elites and the masses. She also pointed out towards the 'impurity' stigma attached with specific type of jobs performed by the 'middleman minorities'; like the 'impure' leather making engagements by the Hakka Chinese in Calcutta. Oxfeld $(1993,2007)$ in context of the Calcutta Hakka tanning community identified the notion of 'social labelling', as the community initially engaged themselves with leather making activities. For her, ethnicity, caste consciousness and religious distinctions play important roles in respect of shaping the leather processing jobs in the city. Hence the concept of 'middleman minorities' related to social labelling is found rational in respect of the Hakka Chinese living in Tangra, Kolkata.

\section{The Hubeinese (Hupeh) dentists}

The natives from Hubei province were renowned as dentists and paper flower makers. Apart from Kolkata, they were also found practicing in other Indian cities of Lucknow, Gorakhpur, Shillong, Bhilai, Bokaro, Madras (Chennai), Bangalore (Bengaluru), New Delhi, Ranchi, etc. After India's independence in 1947, the Government issued order for dentists regarding the necessity of having a medical degree for professional practice. A section of Hubeian dentists, practicing without formal degree found it difficult to carry on. During the Sino-Indian conflict in 1962, when restrictions were placed on the movements of the Chinese people, a good share of them left the country and settled in countries like Pakistan, Hongkong, Singapore, and Australia. Liang (2007) hinted about 50 Hubeinese families in the city (at present dwindling further). 


\section{Dry cleaners from Shanghai}

Laundry service cum dry cleaning is one of the unique forms of Chinese entrepreneurship in Kolkata. The immigrants from Shanghai and Jiangsu provinces were second breed of migrants following Cantonese and Hakka to enter into port cities like Calcutta and Bombay. Zhang and Sen (2013) mentioned that more than $50 \%$ of the immigrants from Shandong originated from the Weifang and Changyi regions, $30 \%$ came from Pingdu and remaining from Yantai. The first of these immigrants perhaps arrived through maritime route during the Guangxu period (1875-1908), initially settling in Sri Lanka and then travelling to India. Some others reached India through Rangoon (Yangon) in Myanmar. Shanghai dry cleaners got financial support from the ethnic Chinese bank situated at Kolkata in their initial setting up of business.

\section{'Bounded solidarity' and harnessing 'social capital' among Chinese overseas in Calcutta}

The global Chinese overseas associations promote ethnic solidarity, kinship ties and the sentiment of 'Greater China' over the foreign soils. Tilly (2007) argued that international migrants help each other through bounded solidarity due to a series of expectations from the members of their group. The social networks of migration from transnational communities are based on trust networks. Formation of native associations (huiguan) is an important facet of community bounded solidarity and feeling of ethnic attachment among the Chinese overseas communities. These guilds or regional native associations provided the passage for cultural centres away from home for sojourning Chinese migrants. It also provided necessary services of compatriot cemeteries. Shrines, temples were made sacred by ashes carried from the hometown temples thus serving the spiritual needs in distant venues (Kuhn 2006, 2008). They also uncovered the late-imperial Chinese to practices that became hallmarks of emigrants living outside China. Zhang and Sen (2013) portrayed the role of Chinese native huiguan run temples, schools and cemeteries which facilitate community gatherings and thus shared cultural space encouraging bounded solidarity, preserving the cultural identity and sense of 'Chineseness' among the communities living in Calcutta/Kolkata. The location of these native associations is mostly around the old Chinatown or 'Cheenapara' circling which the Chinese households and commercial enterprises were established. Apart from the native associations, the economic and business associations such as 'Huan Bao Tannery Council', 'Chinese Tannery Owner's Association' etc. provides the support mechanism for more co-ethnic entrepreneurship quotient solidarity (Table 1).

\section{Role of kinship ties}

Kinship arrangements and family obligations help the newly arrived immigrants if any hindrance occurs by the host society. Oxfeld (1993) examined the role of kinship ties and co-ethnic pool on the family-based entrepreneurial dynamics of the Hakka Chinese community living in Dhapa (Tangra) area. The members actively involve 


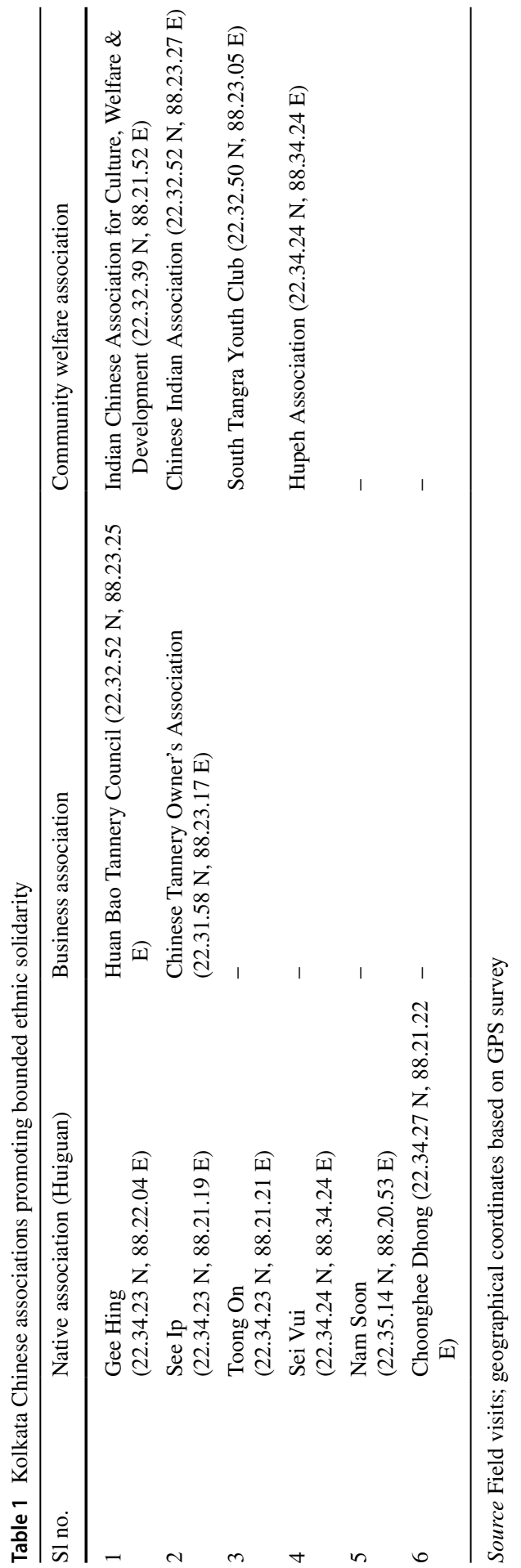


themselves regulating the kinship bonding system to gain economic advantages in those spheres where they find profitable niches. She emphasized on 'time-space compression' by citing Harvey (1989) which involves the breaking down of spatial disorders and thus facilitating rapid movement of humans and capital through greater intra-community link, especially in the case of transnational overseas migrant communities. Recent arrangements are being made by both the young and old locals with their yearlong activities capitalizing on the co-ethnic attachment towards specific ethnic enclave dynamics which this migrant community is proudly carrying for the last two centuries. This is being encouraged by both Government of India and the PRC.

\section{Chinese overseas in Calcutta /Kolkata: the political perspective}

Bose (2013) capitalizing on some of the intelligence records mentioned of canvassing for the Kuomintang (Nationalist) propaganda during British period. There was a network of sub-branches of Kuomintang Association offices established all over the country including at Calcutta (Cheenapara). The Chinese educational policy in India was simple and aimed directly at the benefit of the local Chinese according to the ideals of the Kuomintang. Intelligence records also highlighted about the role of Chinese overseas funded and operated educational institutions for promotion of socio-political ideology among its youth. Educational curricula and text books were imported from China and Chinese languages and traditions were taught to the younger generation (Zhang 2010a, b). The objectives were twofold: nurturing an awareness among the students about the ancestral homeland's rich culture and heritage and preserving the Chinese identity. This helped those students of diasporic and immigrant communities with the ability to speak a Chinese language in their return to China as a linking attribute with the homeland. Thus the schools played a crucial role in preserving the Chinese cultural identity and in the construction of the motherland. Zhang's study (2010a, b) on Chinese education in Calcutta mentioned about the political/ organizational backing behind two Chinese schools: the Mei Kong School at Bentinck Street (Cheenapara) and Pei Mei School (Tangra Chinatown). Both the schools were backed by the Nationalist Chinese Association of Taiwan. The Pei Mei School was run and managed by the Chinese Tannery Association in Tangra (IB file no.236/39 (12) C cited in Bose (2013). The schools being operated with nationalist propaganda received financial and logistic support through the Bank of China situated at Calcutta. The IB report no. 236/39 (12), as cited in Bose (2013) highlighted about some other organizations promoting close ties between China and the Chinese residing in India during the post war/pre-independent era. These were United Overseas Chinese Association, Khong Jai Association and Dhapa Nanching (Nanjing) Club.

During the post-World War II period (of 1945-1947) prior to India's independence, there was a steady rise of communist propaganda in China. This resulted in anti-Kuomintang and pro-Communist ideology links between the two territories. The communist regime was trying to influence the local Chinese of India, including that of Calcutta even before China gained independence from the British. The Communist Government (PRC) of China continued their political activities supporting 
their cause of keeping connected with the overseas Chinese and to diminish the Kuomintang sympathy among them. These strong undercurrents separated the Chinese overseas population in Calcutta/India into two different political schools i.e. the already established 'Kuomintang' v/s the newly emerged 'Communist' regimes. All the then local Chinese associations, business guilds, educational institutions in Calcutta\{ Chinese Chamber of Commerce (Gee Tsing Po), Youth's Association of Dhapa (Liao Ling Chieh), Overseas Chinese Engineering Mechanics Association (Ho Chang), Ssu Yip Association (Chen Yu Yu), Gee Hing Association (Chiu Hui Ming), Hupeh Association (Wei Chien Wu), Shantung Association (I Shao Wen), Huing Association (Chang Chao Tsung), Tungan Association (Huang Yu Chieh), Hupeh Youth's Association, Ex-students Association of Overseas Chinese Middle School, Ex-students Association of Pei Mei School, Leather Syndicate of Dhapa, Bank of China, were diverged and set politically apart. The political propaganda of the Kolkata Chinese, particularly for the then second and third generation was stuck between these two political streams. Bose (2013) highlighted the competition among the Kuomintang and the Communists regarding spreading their propaganda among Chinese overseas in Calcutta. By citing the IB file numbering 236/39 (12) she marked the mounting tussle among the two parties regarding establishment of schools, clubs, temples and promotion of ideologies among trading and community guilds. The older generation of the then overseas community was mostly sympathetic to the Kuomintang and the younger ones were more inclined towards the Communist ideology. Hence the tussle emerged complexity among family dynamics and resulted in breaking up of some of the local Chinese families (Bose 2013).

The Chinese residing in India faced political and social harassments and segregation and polarization of the community due to the Sino-India border conflict (1962). The 'ethnicization' of Chinese identity in India took place with the mass belief that China has betrayed India by breaching the friendship pact of 'Hindi Chini Bha Bhai'. Those who were sympathetic to Communist Government of Zhou En lai were targeted. Over 3000 Chinese Indians were detained in the Deoli internment camp in Rajasthan (Chowdhury 2018; Marsh 2015; Ma and D'Souza 2020). Their properties were seized by the Indian administration under the Enemy Property Act (1968). The episode of political and mass harassment to the community who knew nothing about the war, affected the well organized way of livelihood and their everyday lived practices along with their institutions in India, especially in Calcutta and north-eastern towns of Makum, Digboi, Shillong, Kalimpong and Darjeeling. Many were denied citizenship and remained 'stateless'. Restrictions over their daily actions and occupations led to a series of their out migration from this country.

\section{Chinese overseas in post-liberalized Kolkata: promoting traditional culture, economy and 'Diaspora' Chinese identity}

The major reason behind the out emigration of the Chinese from Kolkata is due to limited economic opportunities. Majority of them are immigrating to Australia, Japan, UK, USA and to Far East. Our field interaction with the senior residents of Kolkata from both the Chinatowns revealed Canada to be the most preferred destination for their children who were born in this city had their schooling here but 
went abroad for better opportunities. However, they carry the emotional bonding with the city and its Chinatowns. Through virtual social media platforms like facebook, instagram they remain connected and their network of transnational active alignment to the greater 'Chineseness' as a identity solemnly promote the 'community cultural capital'. There are a host of virtual groups that operate as transnational 'netnographic' (Internet ethnography) connections for the Indian Chinese Diaspora. Virtual 'Diaspora' groups of the Indian born Chinese who reside in Kolkata or anywhere in India or settled abroad carry the emotional bonding with the city and its Chinatowns. There are a host of virtual groups that operate as transnational 'connections for the Indian Chinese Diaspora culture (Table 2).

Oxfeld (1993) applied the cumulative causation theory in context to the transnational Hakka connectivity between Kolkata and Toronto. Human capital has shifted from Kolkata to Toronto post Indo Sino conflict as a majority moved out to Toronto during 1970s. The shift from a "race-based" immigration policy of the Canadian government in 1967 motivated further. A sustained chain migration among Indian Hakkas has helped this community to grow continuously (Oxfeld 1993) accounting for the increased Hakka population in Toronto. The demands of the local economy too created forces resulting in a distinct Calcutta Hakka identity in Toronto. This transcends the 'network theory' due to which migration becomes easier and less costly and less risky over time because of a growing network of social contacts in the receiving community. Networks through associations too played an important role such as Yin Hua Association, the first Indo-Chinese association with one of the largest numbers (approximating 600) in Toronto launched in 1990 (Chiu 2003). Meizhou Association of Eastern Canada and the Hakka Youth Association both were formed in 1998, while Hakka Helping Hands was in 2000 (Chiu 2003). Recent trend of migration out of Kolkata by the newer generation during the post-liberalization era is from the families of original overseas resident Chinese from Kolkata. This is due to rise in middle-class Chinese families with higher aspirations having educated their children in English medium schools and given better education in Calcutta (field survey, 2016-2019). Referred to as 'Calcutta Chinese' these immigrants in Toronto or London still maintain links (attachments) with their relatives and friends in Calcutta as mentioned by Oxfeld (1993) and Bonnerjee (2010) for these two cities. The flow of individuals is thus not unidirectional. These migrants as a part of the larger 'Calcutta Chinese diaspora' demonstrate their cultural affinity

Table 2 Virtual Indian Chinese overseas group

\begin{tabular}{lll}
\hline Name of the virtual Indian Chinese overseas group & Status of the group & Number of members \\
\hline Chinese families (India + migrated from India) & Private & 533 \\
Hakka from India & Public & 2000 \\
The Indian Chinese Community of India & Private & 625 \\
Chinatown Dragon group & Private & 364 \\
Association of India Deoli Camp Internees, 1962 & Private & Not mentioned \\
Dhapa & Private & Not mentioned \\
\hline
\end{tabular}

Source Social media (facebook, instagram) 
by celebrating during weddings, New Year celebrations, Elders' Day observations at the native associations in Kolkata in addition to sending remittances to the family and relatives here; thus establishing a direct link between the concepts of social capital with the network theory of international migration. Migrant networks are thus sets of interpersonal ties that connect migrants in origin and destination areas through ties of kinship, friendship and shared community origin. On a broader connotation, the global Hakka diaspora family dynamics and newly adopted socio-political contexts became merged on transformation of scaling of ethnic co operations from local to transnational.

The initiative of strengthening global Indian Chinese 'Detainee Diaspora' has been initiated by AIDCI (Association of India Deoli Camp Internees of 1962). It is a major transnational Diaspora Indian Chinese group functioning in Canada. The group assimilates all the families that suffered due to disruption of livelihood on account of forced detention during and after the Sino-Indian conflict of 1962. Even in recent wake of the Galwan border clash between the two countries, the association requested all to keep peace. They want to assure no such repetition of harassments for the community living in India occurs. The oral histories and narratives helped scholars like Li (2005), Marsh (2015), Chowdhury (2018), Ma and D'Souza (2020) to write commendable literatures on the sufferings of the community during the war.

From their intrinsic research titled 'Invisible Chinese' the researchers Pauer et al. (2010) commented Chinatown of Kolkata to be an ethnic enterprise, 'a space of concept' rather than a 'space of place': as a dense and closed in space rather than a tourist spot. It is highly constructed and mediated, a negotiation of authenticity and simulation. They significantly marked the very essence of the twin Chinatowns thriving in this city for about three centuries which needs to be protected and rejuvenated. The success of any Chinatown revitalization plan of action requires an intrinsic participation from the local Chinatown residents. Any kind of external revitalization proposals imposed on this part of the cityscape will not be fruitful until the community themselves believe that redevelopment would be beneficial for them. Thus promotion of tourist places or building of museum inside a heritage spot or decorated Chinese Gates will be ornamental or symbolic when enthusiasm is sorted from the native community associations. In this backdrop, The Community Art Project (TCAP) has and is playing a great role. TCAP is a city based cultural heritage preservation project assigned to preserve and promote traditional culture of Kolkata Chinese community as an intricate part. The project in recent past promoted 'Cheenapara' (old Chinatown) with its diversified facets ranging from craft making to food processing. The Indian Chinese Association (ICA), a heritage promoting agency 'Sahapedia' and a section of enthusiastic local Chinese residents are cordially and actively attached with this initiative. Such endeavours if continued promises greater future achievements. Initiatives have been taken in recent past for promoting traditional Chinese culture and livelihood as depicted in Table 3

Through these initiatives and promotion through social media (like instagram) the TCAP is becoming very popular among the community members (especially the youth) and people outside the community. The TCAP started social media campaigning to promote 'Calcutta Diaspora' and thus the 'Chinese Indian Diaspora' is 
a part of it. The old Calcutta crafts of Chitpur assembled with the crafts of Cheenapara. The people of Kolkata now imagine that the Chinese art and heritage are not only part of transnational Chinese Diaspora but a rich segment of their own culture, thanks to the TCAP initiatives. Heritage confers tangible and intangible cultural artefacts, rituals, myths, crafts etc. as per UNESCO.

Globalization and the opening of market for multinational corporate sector created a new wave of economic resurgence in India after 1991. The wave of corporate investments impacted all traditional dwellings of economic enterprises including Kolkata. The Chinese lost their arc of financial capital investment to regenerate ethnic space as most of the community members emigrated from the city in search of better livelihood. For the last few decades, Chinese enterprises in Kolkata have switched over from traditional to modern day demands. They have given new dimensions to the existing ethnic market of the city. Endeavours like beauty salons, tattoo parlours, food processing and provision units, photography and travel assistance are signalling towards a re-production of ethnic proprietorship for the Kolkata Chinese. Transformation of Chinese owned businesses and ancestral occupations in the city indicates tendency towards transnational multi corporatization. Starting from food processing to jewellery and gem manufacturing, logistics to photography, the once 'middleman minority' economy of the overseas Chinese in Calcutta now have modified towards outbound non-enclaved ventures. Chinese owned enterprises have started diffusion of their units beyond the limits of the Chinatown walls. As per the yellow pages and field observations, a considerable number of Chinese overseas run business establishments have been established and even new branches of some old Chinatown ventures or newer ventures of the same business units have spread to satellites like Salt Lake, Lake Town and Rajarhat New Town areas. The beauty parlours and tattoo parlours cater the modern youth requirements towards their westernized style orientation. The Diaspora 'motherland' connection is still felt through naming of overseas enterprises such as Beijing, Formosa Inn, Hong Kong, Shanghai, Mandarin gourmet, Ming garden, Nanking etc. These are spatially concentrated mostly around the Chinese nucleus around Tiretta Bazaar and Tangra.

\section{Initiatives taken from PRC, consulate Kolkata to strengthen Chinese overseas tie}

China's overseas policy has two dimensions - a foreign and domestic dimension. The foreign dimension involves the ethnic Chinese abroad and the countries in which they reside (Zerba 2008). Similar to the KMT (Kuomintang/Nationalist), the communist government established the Overseas Chinese Affairs Commission (OCAC) to manage both the foreign and domestic aspect of overseas Chinese work. The OCAC coordinated with other governmental agencies to handle overseas Chinese affairs to protect the interests of the Chinese abroad. Consequently, the PRC Consulate to Kolkata is active in promoting the Chinese overseas culture and heritage and preservation of tradition for the last few years. The Consulate invites members of local Chinese Associations of ICA (Indian Chinese Association) and/or CIA (Chinese Indian Association), local representatives to join such events. These recent initiatives have been highly successful and popular from all perspectives. Involving all stake holders the aim is to construct a key link to promote 'China' in this part 


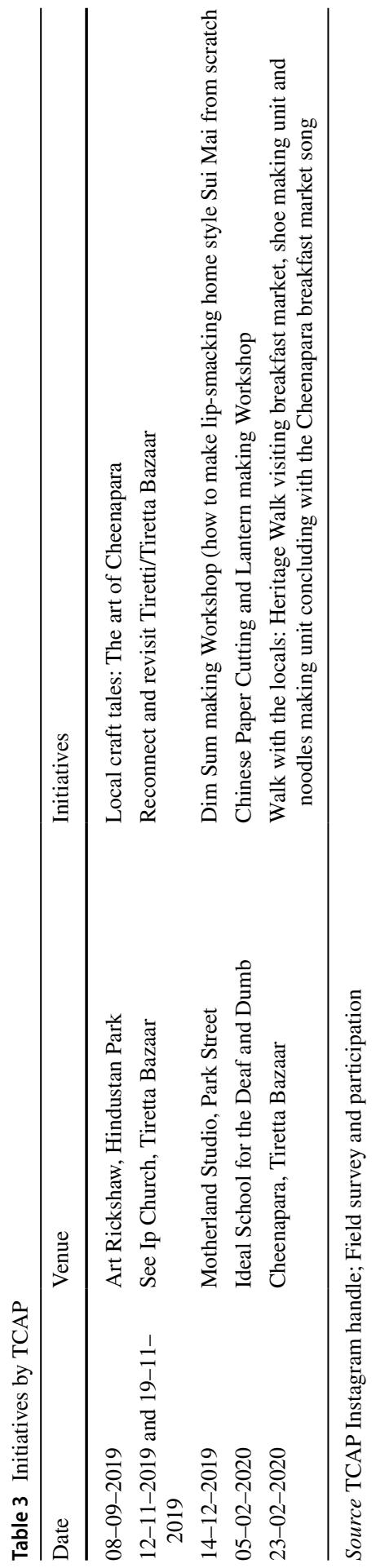


of India (i.e. Kolkata) as a part of PRC's 'soft diplomacy' in the Jinping era. Since 2016 the first author covered a host of events, collected information of all such initiatives of which the recent ones of 2019 and 2020 are depicted in Table 4.

\section{Kolkata Chinese and Diaspora connections with their overseas compatriots}

The Post-modern version of Chinese identity formation emerged as a crucial issue in context to Diaspora and remittance research. Oxfeld (1993) by citing Friedrich Barth (1969) mentioned the importance of ethnic identity makers, which is found highly instrumental such as common ancestry (through global Hakka and Cantonese associations), shared cultural history, and feelings of shared struggles for the Chinese in Calcutta regarding their ethnic identity formation through Association of India Deoli Camp Internees, 1962. For Wong (2003) 'hybrid' identity among Chinese overseas has become a prime notion of their contemporary belonging. Gosling (1983) in his study highlighted how the Chinese overseas adopted identity management strategies to negotiate their position according to the socio-political circumstances of the host country. These ranged from adaptation to accommodation and acculturation to assimilation. Wang (1991) classified the Chinese overseas 'identity' formation in context to their local National identity and Cultural ethnic identity.

For the Chinese in Kolkata, 'Chineseness' means a biological and ethnic connection to their roots and thus they keep their cultural ties alive with their compatriots living in different countries across the globe including Singapore, Taiwan, Malaysia, Hong Kong, Thailand, Australia, United States and Canada. They connect through a transnational link of immigrant Diaspora networks run by Chinese Overseas associations, huiguans, trading guilds, social media etc. A part of the global Indian Chinese Diaspora connects with their compatriots worldwide both through physical and virtual mediums. This is found instrumental in keeping their post-global ties active. These include showing solidarity with their compatriots living in mainland China, Taiwan or elsewhere, participating in global Diaspora conferences, etc. The ICT connections, virtual and physical transnational Chinese overseas gatherings between Chinese in Kolkata (India) and their compatriots living in various cities rejoice in their belonging and Diaspora identity and keeping it alive in this post-globalization period. Early last year in February, 2020 with the global Covid-19 outbreak the Hupeh Association of Kolkata, comprising of the dentist families expressed their solidarity with the people of Wuhan, the capital of Hubei (Hupeh) province. We, the authors also took part in the campaign as non-Chinese friends to wish recovery for the people of Wuhan. Some members of the fragile Hupeh fraternity in Kolkata, having their exclusive community meeting space and temple at the top floor of the Sei Voi Association's building expressed concerns about their relatives residing in China and other parts of the globe as revealed through an interaction with them during our field survey. The Chinese Overseas Association of Kolkata supported in the form of medical kits, masks and other emergency items through PRC Consulate in Kolkata to China. The Cantonese community, hailing from Pearl River delta region is also having their varied clan origins of SiWi (Sei Voi), Nam Soon and Sze Yap (See Ip). Inside the See Ip temple, the authors observed testimonials, wish letters 


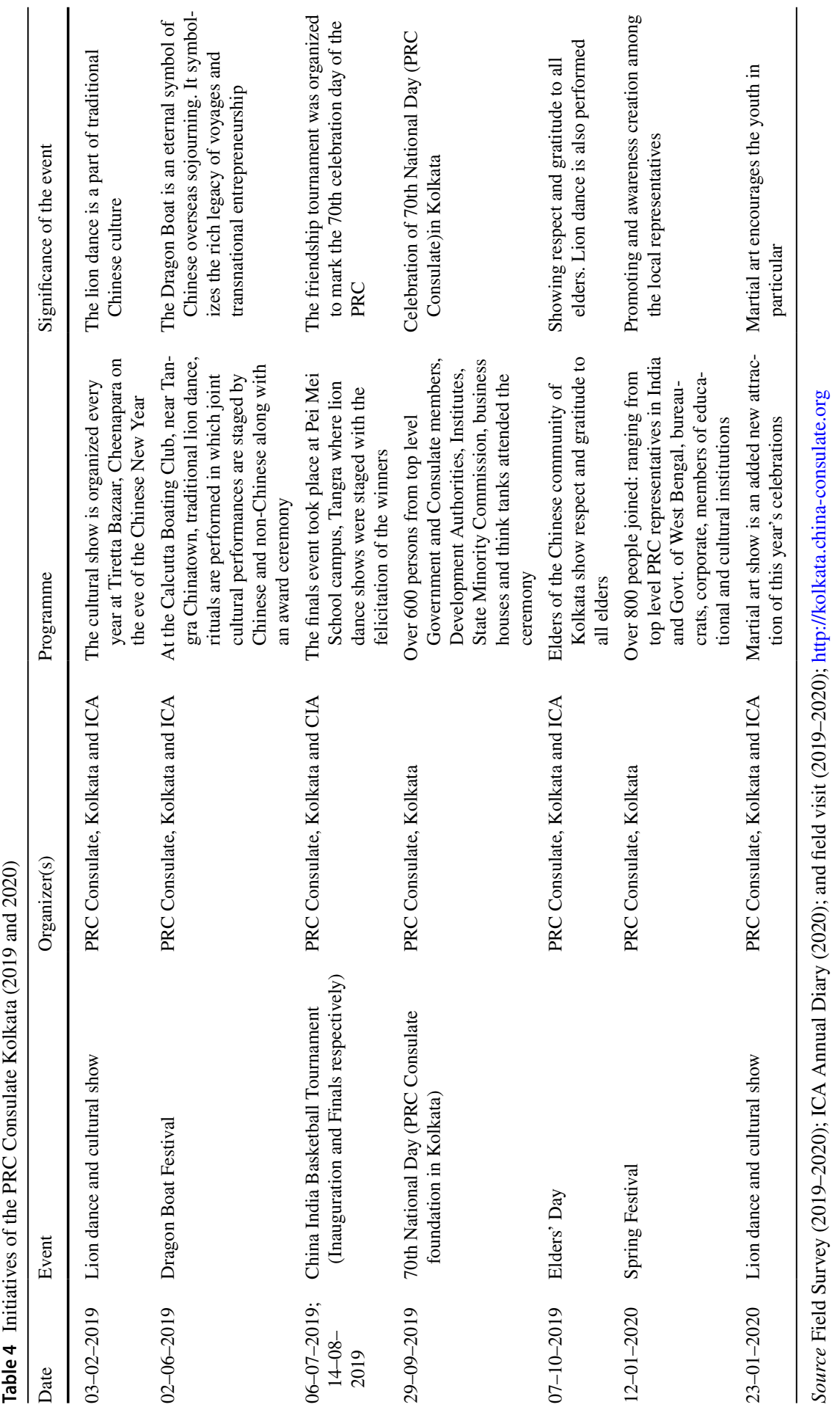


and Chinese New Year calendars besides having messages from their compatriots from Kowloon (Hong Kong) and Chongqing. The Cantonese in Kolkata through these overseas associations connect with their friends and relatives living abroad. The Hakka, being the largest Chinese overseas Diaspora, connects with its compatriots through virtual and physical mediums. Through the social media platforms, the community of 'Hakka from India' has several thousands of members with whom they share and enjoy their everyday Diaspora belonging. Sharing of posts on their celebrations, entrepreneurship, meetings encourage their compatriots to connect to their ethnic roots and identity. Ethnic food Diaspora among the Chinese overseas is another significant Diaspora identity connection. Social media group named as 'The Chindian Diaries' of Singapore emphasize on the cultural assimilation, mixed racial origins, marriages among the Chinese and Indians. In a virtual post they marked an interesting food-ethnicity notion of six types of 'Zong Zi' (traditional Chinese rice dish) from various dialect and ethnic groups in Singapore as found in the said social media account. A global Hakka conference has been hosted very recently in July 2021 in Toronto, Canada where Hakkas from across the world including those from Kolkata participated via the virtual medium. Oxfeld (1993) mentioned about the struggles and success of Hakka migrants from Calcutta in Toronto in establishing their niche amidst their Cantonese counterparts who migrated from India and Hong Kong. Being considered as 'guest' people, the surname groups among Indian (Calcutta) Hakkas in Toronto played a vital role she opined.

\section{Conclusion}

Geographers presently are adopting the multiple methods (qualitative, quantitative and cartographic) in data analysis from multiple sources. The phenomenon of emigration of Chinese was on account of several internal and external events. In the late nineteenth century the pushes and pulls produced the coolie trade, the credit ticket and steerage passage (Qin 2003) system on steamships after 1870 and a continuation of the earlier chain migration method. This was due to more hospitable policy towards Asian immigrants with the 'Exclusion' and 'Whites only' legislation repealed, and more generous immigration terms granted. Irrespective of the destination area the composition was males: the concept of 'sojourning' (Woon 1983-1984; Reevas and Mountford 2011; Song 2019) single man of the father-son-nephew family. Since the turn of the century (1900-1964) a radically different development was the growing migration of women and children and the reconstitution of families abroad. Government policies, economic and political conditions in the sending areas, policies in the receiving areas and new technological developments in transportation making it cheaper and electronic communication, changed the composition of Chinese Overseas post-globalization.

The grounding of migration theories with the Chinese overseas from the case study of a Chinatown less studied - that of Calcutta/Kolkata on a micro level was done in the process. Tracing the roots of the Chinese Overseas enclaves, dimensional variation of ethnic professions/economic activities among these Chinese immigrants led to a sectoral specialization and to the formation of twin 
Chinatown. From 'Bounded Solidarity' and harnessing of 'social capital' till articulating the political identity of the Chinese Overseas in post-liberalized Kolkata the holistic and integrated approach adopted by us has given a fresh look on this unique cityscape. The Census enumeration of 1921 and 1931 reflected the Confucian identity as the Chinese community residing in Calcutta was listed religion wise as Confucian or Buddhist observed Dasgupta (2009) in her work. This reflects the third moment of Shelly Chan's (2018) with a debate on Confucianism and Chinese identity. The communities were marked by the host society inside Kolkata in respect of their economic niche as well, i.e. Cantonese carpenters, Hakka tanners, shoe makers and shoe sellers, Hubeinese or Hupeh dentists, Shandong silk traders and Shanghai dry cleaners. Compared to the Hakkas in preliminary phases of settling down, the Cantonese gathered sufficient wealth (Liang 2007) after working hard in British shipping yards, later establishing as carpenters and furniture entrepreneurs. The changing geo political global and internal dynamics, change in Chinese medium to a local educational medium of instruction and curricula, a rising middle-class with aspirations of a neoglobalized economy through exposure to new images and ideas of the 'good life' (de Haas et al. 2019) has had an impact in the dwindling population, in a diversification of their occupational ethnic traits, as well as reviving and revitalizing the rich tradition and culture attempts.

Very briefly has the paper thrown light on the political factionalism within the Chinese community in Kolkata. Focus towards the end of the twentieth century of post-liberalization period has been done to reflect the current diasporic trend as well. From our field surveys, interactions with the community, our participation in their socio-cultural events we gained familiarity with their customs, their occupational ventures, their rich tangible and intangible heritage. We have visited and re visited the Huiguans, the clubs, the temples, the restaurants, the tanneries, their private quiet All Souls' Day Celebration, their public participations through boat races and dragon dance, the breakfast bazaar, etc. We observed their festive occasions, participated in the Heritage Walk, to have a feel and flavour of the rich tradition of Kolkata Chinatown. In Kolkata such activities are performed by the dwindling Indian born Chinese at Tiretta Bazar and Tangra, arranged by the Indian Chinese Association with support from local Consulate of People's Republic of China (PRC) encouraging the community to emphasize more on community capital accumulation. Initially, the Chinese immigrants in Kolkata carved out niches in four major occupations: carpentry, shoemaking, tannery and dentistry. As the number of Chinese immigrants grew in the early to mid twentieth century, they began diversifying into new businesses, such as laundry, restaurants and beauty salons. They engaged themselves in these professions because of the specific skills they possessed. Later due to several geopolitical reasons they have diversified leaving rich imprints on this city. A keen enthusiasm to revive and keep intact their traditional culture at the same time follow the trend as in the neo liberalized era with active support from all stakeholders will definitely revitalize this little known yet unique Chinatown of Kolkata, the City of Joy. 
Acknowledgements We express our heartfelt thanks to Ms. Labani Sarkar for her kind assistance regarding preparation of the maps.

Funding Not applicable.

Data availability All data analysed are contained in the paper.

\section{Declarations}

Conflict of interest The authors declare no conflicts.

\section{References}

Alabaster C (1858) The Chinese colony in Calcutta. Calcutta Rev 31(62):368-389

Baser B (2014) The awakening of a Latent Diaspora: the political mobilization of first and second generation Turkish Migrants in Sweden. Ethnopolitics 13(4):355-376

Bonacich E (1973) A theory of middleman minorities. Am Sociol Rev 38:583-594

Bonnerjee JJ (2010) Neighbourhood, City, Diaspora: identity and belonging for Calcutta's Anglo-Indian and Chinese Communities, Queen Mary University of London

Bose NK (1968) Calcutta 1964: a social survey. Lalvani Publishing House, Mumbai

Bose A (2013) Kolkatar China Samprodayer Itihas (1781 AD-2001 AD) PhD. Thesis, The University of Burdwan. http://hdl.handle.net/10603/50365. Accessed 10 March 2019

Bracken G (2018) Treaty ports in China: their genesis, development and influence. J Urban Hist 45(1):168-176

Chan H (1999) The identity of the Chinese in Australian history. Qld Rev 6(2):1-10

Chan S (2018) Diaspora's homeland: modern China in the age of global migration. Duke University Press, Durham

Chiu SS (2003) Ethnic identity formation: a case study of Caribbean and Indian Hakkas in Toronto. MA thesis, York University. https://www.yumpu.com/en/document/view/31946924/ethnic-identityformation-a-case-study-of-caribbean-and-ceris. Accessed 5 July 2019

Chowdhury R (2018) Chinatown Days. Mac Milan, India

Consulate of People's Republic of China in Kolkata. https://kolkata.china-consulate.org. Accessed 06 Aug 2020

Dasgupta K (2009) Mapping the spaces of minorities: Calcutta through the last century. In: Banerjee H, Gupta N, Mukherjee S (eds) Calcutta Mosaic: essays and interviews on the minority communities of Calcutta. Anthem Press, Kolkatta, pp 22-69

de Haas H, Natter K, Vezzoli S (2018) Growing restrictiveness or changing selection? The nature and evolution of migration policies. Int Migr Rev 52(2):324-367

de Haas H, Czaika M, Flahaux M, Mahendra E, Natter K, Vezzoli S, Villares-Varela M (2019) International migration: trends, determinants and policy effects. Popul Dev Rev 45(4):885-922

Deng KG (2010) Book review of the coolie trade, the traffic in Chinese labourers to Latin America, 1847-1874 by Arnorld J. Meagher. Aust Econ Hist Rev 50(1):99-110

Downs JM (1997) The Golden Ghetto: the American commercial community at canton and the shaping of American China Policy, 1784-1844. Hong Kong University Press, Hong Kong

Frazier JW, Tettey-Fio E, Henry NF (eds.) (2010) Race, ethnicity and place in a changing America. State University of New York Press, Albany

Goodkind D (2019) The Chinese diaspora: historical legacies and contemporary trends. https://www.census.gov/content/dam/Census/library/workingpapers/2019/demo/Chinese_Diaspora.pdf. Accessed 17 July 2020

Gosling P (1983) Changing Chinese identities in Southeast Asia: an introductory review. In: Gosling P, Lim L (eds) The Chinese in Southeast Asia: identity, culture and politics. Maruzen Asia, Singapore

Grant C (1862) Anglo-Indian domestic life: a letter from an artist in India to his mother in England. Baptist Mission, Calcutta 
Indian Chinese Association for Culture, Welfare and Development (2016, 2017, 2020) Annual Diary and Yellow Pages

Jorgen C (2002) Migration in the age of involuntary immobility: theoretical reflections and Cape Verdean experiences. J Ethn Migr Stud 28(1):05-42

Kuhn PA (2006) Why China historians should study the Chinese Diaspora, and vice-versa. J Chin Overseas 20(2):163-182

Kuhn PA (2008) Chinese among others: emigration in modern times. Rowman \& Littlefield, Lanham

Lai DC (1988) Chinatowns: towns within cities in Canada. The University of British Columbia Press. https://books.google.co.in. Accessed 17 March 2017

Li PS (2005) The rise and fall of Chinese immigration to Canada: newcomers from Hong Kong special administrative region of China and Mainland China, 1980-2002. Int Migr 43(3):09-34

Li X, Lee J (2005) Chinese in Canada. In: Ember M, Ember C, Skoggard I (eds) Encyclopedia of Diasporas. Springer, Boston

Liang J (2007) Migration patterns and occupational specialisations of Kolkata Chinese: an insider's history. China Rep 43(4):397-410

Liu $\mathrm{H}$ (2005) New migrants and the revival of overseas Chinese nationalism. J Contemp China 14(43):291-316

Liu H, Dongen EV (2016) The Chinese Diaspora. Chinese: Oxford Bibliographies. http://www.oxfordbibl iographies.com/view/document/obo9780199920082/obo97801999200820070.Xml. Accessed 20 Aug 2020

Lo L (2006) Changing geography of Toronto's Chinese ethnic economy. In: Kaplan DH, Li W (eds) Landscapes of ethnic economy. Rowman and Littlefield, Lanham, pp 83-96

Lo L, Wang S (1997) Settlement patterns of Toronto's Chinese immigrants: convergence or divergence? Can J Reg Sci 20:49-72

Luo W (2017) More Chinese students set to study overseas. The Daily Telegraph, March 21 Issue. http:// www.telegraph.co.uk/news/world/china-watch/society/more-students-to-study-overseas. Accessed 14 July 2019

Ma LJC, Cartier C (eds.) (2003) The Chinese Diaspora: space, place, mobility and identity. Rowman \& Littlefield, Lanham

Ma J, D'Souza D (2020) The Deoliwallahs: the true story of the 1962 Chinese-Indian Internment. Pan Macmillan

Marsh Y (2015) Doing time with Nehru: life before the India-China border war of 1962. Zubaan, Kolkata

Mckeown A (1999) Conceptualizing Chinese Diasporas, 1842-1949. J Asian Stud 58(2):306-337

McKeown A (2010) Conceptualizing Chinese Diasporas, 1842 to 1949. J Asian Stud 58(2):1842-1949

Mei J (1979) Modern China. Penn. Hist Rev 5(4):463-501

Mizuoka F (1976/2017) British Colonialism and illegal immigration from mainland China to Hong Kong. Jpn Contrib Hist Geogr Thought 11: 33-66

MD Dictionary Version E (1958) International union for the scientific study of population. Department of Economic and Social Affairs, New York

Morse HB (1910) The international relations of the Chinese empire: the period of conflict, 1834-1860, Longmans, Green and Company

NATMO (2010) Atlas of Calcutta City, Kolkata

Nield R (2015) China's foreign places: the foreign presence in China in the Treaty Port Era, 1840-1943. Hong Kong University Press, Hong Kong

Oxfeld E (1993) Blood, sweat and mahjong: family and enterprise in an overseas Chinese community. Cornell University Press, Ithaca and London

Oxfeld E (2005) Chinese in India. In: Ember C (ed) Encyclopaedia of Diasporas. Kluwer Academic Publishers, Boston

Oxfeld E (2007) Still Guest people: the reproduction of Hakka identity in Kolkata, India. China Rep 43(4):411-435

Pauer L, Wilson A D, Herzog J, de Meuron P, Herz M, Rahbaran S, Zhou Y (2010) Invisible Chinese. Eth Stduio, Basel

Piore M (1979) Birds of passage: migrant labor and industrial societies. Cambridge University Press, Cambridge

Poston DL, Wong JH Jr (2016) The Chinese diaspora: the current distribution of the overseas Chinese population. Chin J Sociol 2(3):348-373

Qin Y (2003) A century-old puzzle: the six companies' role in Chinese labor importation in the nineteenth century. J Am-East Asian Relat 12(3/4):225-254 
Redclift V (2017) The demobilization of diaspora: history, memory and Latent identity. Global Netw 17(4):500-517

Reeves K, Mountford B (2011) Sojourning and settling: locating Chinese Australian history. Aust Hist Stud 42:111-125

Roy K, Basu S (2020) Occupational diversity and locational dynamics of Chinese owned enterprises in Kolkata. GeoJournal 85:19-40

Sales R, D’Angelo A, Liang X, Montagna N (2009) London's Chinatown: branded place or community space? In: Donald SH, Kofman E, Kevin C (eds) Branding cities: cosmopolitanism, parochialism and social change. Routledge, London

Sassen S (1991) The global city: New York, London. Princeton University Press, Princeton, Tokyo

Skinner GW (1957) Chinese society in Thailand: an analytical history. Cornel University Press, Ithaca

Social Media accounts of The Community Art Project (TCAP), various Indian Chinese Diaspora community groups, Association of Deoli Camp Internees India 1962 (AIDCI), The Chindian Diaries

Song Z (2019) Global Chinese Diaspora. In: Ratuva S (ed) The Palgrave Handbook of Ethnicity. Palgrave Macmillan, Singapore

Suryadinata L (2015) The making of Southeast Asian nations: state, ethnicity. World Scientific Publishing, Indigenism and Citizenship

Tilly C (2007) Trust networks in transnational migration. Sociol Forum 22(1):03-24

Wang G (1991) China and the Chinese overseas. Times Academic Press, Singapore

Wang G (2000) The Chinese overseas: from earthbound China to the quest for autonomy. Harvard University Press, Cambridge

Wong L (2003) Belonging and Diaspora: the Chinese and the Internet, First Monday 8(4). https://first monday.org/ojs/index.php/fm/article/download/1045/966. Accessed 18 July 2021

Wong L (2007) The Canadian Chinese Exclusion Act and the veterans who overcome it. History and Perspectives, Chinese Historical Society, Chinese America

Woon Y (1983-1984) The voluntary sojourner among the overseas Chinese: myth or reality? Pacific Affairs 56(4): 673-690

Yee HS, Lo SH (1991) Macao in transition: the politics of decolonization. Asian Surv 31(10):905-919

Zerba S (2008) The PRC's overseas Chinese policy, MA thesis, Naval Postgraduate School, California. https://www.researchgate.net/publication/235043811_The_PRC's_Overseas_Chinese_Policy/stats. Accessed 11 Feb 2021

Zhang X (2010a) Preserving cultural identity through education: the schools of the Chinese Community in Calcutta, ISEAS, Singapore

Zhang X (2010b) The Bowbazar Chinatown, India. Int Centre Q 36(3/4):396-413

Zhang X, Sen T (2013) The Chinese in South Asia. In: Tan C (ed) Routledge handbook of the Chinese Diaspora. Routledge, London and New York, pp 205-226 